University of Nebraska - Lincoln

DigitalCommons@University of Nebraska - Lincoln

Publications from USDA-ARS / UNL Faculty

U.S. Department of Agriculture: Agricultural

Research Service, Lincoln, Nebraska

2006

\title{
Upper Profile Changes Over Time in an Appalachian Hayfield Soil Amended with Coal Combustion By-products
}

\author{
X. Zhou \\ Virginia Polytechnic Institute and State University, xzz2@psu.edu \\ K. D. Ritchey \\ United States Department of Agriculture \\ R. B. Clark \\ United States Department of Agriculture \\ N. Persaud \\ Virginia Polytechnic Institute and State University \\ D. P. Belesky \\ United States Department of Agriculture
}

Follow this and additional works at: https://digitalcommons.unl.edu/usdaarsfacpub

Part of the Agricultural Science Commons

Zhou, X.; Ritchey, K. D.; Clark, R. B.; Persaud, N.; and Belesky, D. P., "Upper Profile Changes Over Time in an Appalachian Hayfield Soil Amended with Coal Combustion By-products" (2006). Publications from USDAARS / UNL Faculty. 584.

https://digitalcommons.unl.edu/usdaarsfacpub/584

This Article is brought to you for free and open access by the U.S. Department of Agriculture: Agricultural Research Service, Lincoln, Nebraska at DigitalCommons@University of Nebraska - Lincoln. It has been accepted for inclusion in Publications from USDA-ARS / UNL Faculty by an authorized administrator of DigitalCommons@University of Nebraska - Lincoln. 
This article is a U.S. government work, and is not subject to copyright in the United States.

Communications in Soil Science and Plant Analysis, 37: 1247-1267, 2006

Copyright (C) Taylor \& Francis Group, LLC

ISSN 0010-3624 print/1532-2416 online

DOI: $10.1080 / 00103620600623574$

\title{
Upper Profile Changes Over Time in an Appalachian Hayfield Soil Amended with Coal Combustion By-products
}

\author{
X. Zhou \\ Virginia Polytechnic Institute and State University, \\ Blacksburg, Virginia, USA
}

K. D. Ritchey and R. B. Clark

United States Department of Agriculture/Agricultural Research Service/Appalachian Farming Systems Research Center, Beaver, West Viginia, USA

\section{N. Persaud}

Virginia Polytechnic Institute and State University, Blacksburg, Virginia, USA

\section{P. Belesky}

United States Department of Agriculture/Agricultural Research Service/Appalachian Farming Systems Research Center, Beaver, West Viginia, USA

\begin{abstract}
Large amounts of flue gas desulfurization (FGD) and fluidized bed combustion (FBC) by-products from burning coal, consisting primarily of gypsum, are available for potential use as a soil amendment. However, information is limited on longer-term changes in chemical and physical properties induced over time and over small depth increments of the upper soil profile after applying these amendments. This study examined longer-term effects in an abandoned Appalachian pasture soil amended with various liming materials and coal combustion by-products (CCBPs). Soil chemical and physical properties were investigated over time and depths.
\end{abstract}

Received 10 January 2005, Accepted 8 September 2005

Address correspondence to X. Zhou, Department of Crop and Soil Sciences, 116 ASI Building, Pennsylvania State University, University Park, PA 16802, USA. E-mail: xzz2@psu.edu 
The results indicated limited dissolution and movement of the calcium $(\mathrm{Ca})$ and magnesium $(\mathrm{Mg}$ ) applied with the chemical amendments, except for $\mathrm{Ca}$ and $\mathrm{Mg}$ associated with sulfate. However, sufficient dissolution occurred to cause significant increases in exchangeable $\mathrm{Ca}$ and $\mathrm{Mg}$ and decreases in exchangeable $\mathrm{Al}$ that were reflected in corresponding increases in soil $\mathrm{pH}$. These beneficial effects persisted over time and were confined to the upper $0-$ to $15-\mathrm{cm}$ depth of the profile. The greatest benefits appeared to be in the upper 0- to $5-\mathrm{cm}$ surface layer. Both $\mathrm{Ca}$ and $\mathrm{Mg}$ applied as calcitic dolomitic limestone tended to be immobilized in the upper 0to 5-cm layer of the soil profile; Ca more so than $\mathrm{Mg}$. The presence of S applied in the FGD and FBC amendments appeared to enhance the mobility of $\mathrm{Ca}$ and $\mathrm{Mg}$. The ratio of $\mathrm{Ca} / \mathrm{Mg}$ in $\mathrm{HCI}$ extracts from the calcitic dolomitic treatment was close to that of applied calcitic dolomite, implying that the inactive component in soil might be the original calcitic dolomite particles. Soil physical properties measured over small depth increments showed that application of the amendments improved the saturated hydraulic conductivity only in the upper $0-$ to $5-\mathrm{cm}$ depth and had little or no significant effect on the dry bulk density and plant-available water.

Keywords: Gypsum, limestone, soil $\mathrm{Ca}$ and $\mathrm{Mg}$ mobility, soil chemical/physical properties

\section{INTRODUCTION}

Limited soil nutrient availability and water deficits can restrict cool-season forage plant productivity on the relatively shallow and eroded pasture soils that are common in much of the Appalachian region (Belesky et al.2002). In these acidic soils $(\mathrm{pH}<5.5)$, the existence of mineral element toxicities [e.g., aluminum $(\mathrm{Al})$ and manganese $(\mathrm{Mn})$ ] and deficiencies [e.g., phosphorus $(\mathrm{P})$, calcium $(\mathrm{Ca})$, magnesium $(\mathrm{Mg})$, potassium $(\mathrm{K})$, and boron $(\mathrm{B})]$ limit growth of pasture species. In addition, soil compaction from grazing activity can negatively influence many soil physical properties (e.g., bulk density and hydraulic conductivity) and ultimately the growth, development, and productivity of pasture swards. Because of these chemical and physical constraints, unamended Appalachian pastures do not produce sufficient forage to adequately sustain the nutritional needs of most grazing animals.

Nutrient imbalances and occasionally physical constraints (e.g., crusting, infiltration, and aggregate stability) in soil can be alleviated through addition of chemical amendments. Limestone $\left[\mathrm{C}_{\mathrm{a}} \mathrm{CO}_{3}\right.$ or $\left.\mathrm{CaMg}\left(\mathrm{CO}_{3}\right)_{2}\right]$ is commonly surface applied to hilly pastures and hayfields to increase soil $\mathrm{pH}$ and provide $\mathrm{Ca}$ and $\mathrm{Mg}$ for plant growth. However, movement of $\mathrm{Ca}$ to deeper layers from surface-applied limestone is slow unless very high rates are applied (Brown et al. 1956).

Calcium from gypsum products is generally more soluble than $\mathrm{Ca}$ from limestone and may more readily leach to subsoils (Ritchey et al. 1995). Gypsum also acts as a source of $S$ to plants. Gypsum does not neutralize soil acidity the way that limestone and calcium hydroxides do, but it can 
have some minor benefits in overcoming growth restriction associated with low soil $\mathrm{pH}$. Aluminum toxicity, a widespread problem in acidic soils that inhibits root growth and nutrient uptake, can be partially alleviated by application of gypsum because it increases exchangeable Ca:Al ratios (Wendell and Ritchey 1996). In addition, gypsum can bring about changes in physical characteristics of some high $\mathrm{Mg}$ or sodium (Na) soils by decreasing surface crusting, enhancing water infiltration, and keeping soil aggregated, and these conditions can indirectly benefit other soil physical properties (Wong and Ho 1991; Iiyas, Miller, and Qureshi 1993). However, there are few reports about the effects of gypsum on physical properties of Appalachian region soils not affected by high $\mathrm{Na}$ or $\mathrm{Mg}$ concentrations.

Large amounts of coal combustion by-products (CCBPs), declared nonhazardous wastes by the U.S. Environmental Protection Agency, are increasingly available in the eastern United States. Gypsum in FGD is relatively pure compared to mined agricultural gypsum. It is composed mainly of $\mathrm{Ca}$ sulfate and carbonate, and has been applied to acidic soils as a soil amendment. The fludized bed combustion by-products (FBCs) consist of mixtures of Ca sulfate, sulfite, oxide, hydroxide, and carbonate plus bottom ash and other materials that can increase soil pH (Zaifnejad et al. 1996) and reduce Al toxicity in acidic subsoil layers (Wendell and Ritchey 1996). These by-products have been shown to benefit shoot and root growth and yields of several pasture species grown on acidic soils (Clark et al. 1995), although they may be classified as hazardous waste because they have $\mathrm{pH}$ values greater than 12. Information is limited on long-term changes in soil chemical and physical properties occurring over small depth increments of acidic hayfield soils after amendment with CCBPs. The overall objective of this study was to examine longer-term effects of application of different CCBPs on upper soil profile chemical and physical properties in an abandoned Appalachian hayfield. Specific objectives were 1) to determine how exchangeable $\mathrm{Ca}, \mathrm{Mg}, \mathrm{Al}$, sulfur $(\mathrm{S})$, and $\mathrm{pH}$ changed over time in the 0 - to $15-\mathrm{cm}$ and $15-$ to $30-\mathrm{cm}$ layers of the soil profile following the application of traditional liming materials and CCBPs, and 2) to determine differences in the effect of traditional liming materials and CCBPs on these same chemical properties, dry bulk density $\left(\rho_{\mathrm{b}}\right)$, saturated hydraulic conductivity $\left(\mathrm{K}_{\text {sat }}\right)$, and plant-available water (PAW) over small depth increments of the soil profile.

\section{MATERIALS AND METHODS}

Samples were collected fiom a larger experiment installed on a site (Gilpin silt loam) in southern West Virginia ( $\left.37^{\circ} 48^{\prime} 45^{\prime \prime} \mathrm{N}, 80^{\circ} 58^{\prime} 45^{\prime \prime} \mathrm{W}\right)$ that was considered representative of abandoned pastures in the Appalachian region (Ritchey and Snuffer 2002). This experiment was conducted on a welldrained hillside with 8 to $15 \%$ slopes. It had been abandoned for three 
Table 1. Combinations of amendments applied to experimental plots in 1993 and the amounts of nutrient elements added

\begin{tabular}{lrrrrrrrr}
\hline & DL & FGD-22 & FBC-26 & MgO & TNE & Ca & Mg & S \\
\cline { 2 - 8 } Treatment & $\begin{array}{c}(\mathrm{Kg} \\
\left.\mathrm{ha}^{-1}\right)\end{array}$ & $\begin{array}{c}(\mathrm{Kg} \\
\left.\mathrm{ha}^{-1}\right)\end{array}$ & $\begin{array}{c}(\mathrm{Kg} \\
\left.\mathrm{ha}^{-1}\right)\end{array}$ & $\begin{array}{c}(\mathrm{Kg} \\
\left.\mathrm{ha}^{-1}\right)\end{array}$ & $\begin{array}{c}(\mathrm{Kg} \\
\left.\mathrm{ha}^{-1}\right)\end{array}$ & $\left(\mathrm{g} \mathrm{m}^{-2}\right)$ & $\left(\mathrm{g} \mathrm{m}^{-2}\right)$ & $\left(\mathrm{g} \mathrm{m}^{-2}\right)$ \\
\hline Check & 0 & 0 & 0 & 0 & 0 & 0 & 0 & 0 \\
DL & 4650 & 0 & 0 & 0 & 4840 & 97.7 & 51.2 & 0 \\
MgO & 0 & 0 & 0 & 526 & 1290 & 0 & 26.8 & 0 \\
FGD + DL & 4650 & 16,000 & 0 & 0 & 5640 & 478.5 & 51.6 & 345.6 \\
FGD + MgO & 0 & 16,000 & 0 & 526 & 2090 & 380.8 & 27.2 & 345.6 \\
FBC + MgO & 0 & 0 & 15,000 & 526 & 9540 & 619.3 & 32.3 & 261.0 \\
\hline
\end{tabular}

decades and then rotary mowed annually for 10 years but was not otherwise used for fodder or grazing. Grasses of low nutritive value, primarily red fescue (Festuca rubra L.), poverty grass (Danthonia specata L.), and broom sedge (Andropogon virginicus L.), covered $28 \%$ of the site. It was estimated that $66 \%$ of the site was covered by broadleaf weeds with goldenrod (Solidago juncea Ait.) being the most prevalent.

Plots $(8 \times 3 \mathrm{~m})$ were laid out in 1993 (Ritchey and Snuffer 2002). In July 1993, fertilizer $\left(27 \mathrm{~kg} \mathrm{ha}^{-1} \mathrm{~N}, 132 \mathrm{~kg} \mathrm{ha}^{-1} \mathrm{P}\right.$, and $\left.132 \mathrm{~kg} \mathrm{ha}^{-1} \mathrm{~K}\right)$ was surface applied to each plot. Combinations of calcitic dolomitic limestone (DL), CCBPs (FGD-22 and FBC-26), and a lightly calcined magnesite $\mathrm{MgO}$ fertilizer (Fert-o-Mag, American Minerals, Wilmington, DE) ${ }^{1}$ as specified in Table 1 were surface applied at the same time. Chemical properties of the amendments (Clark et al. 1995) used are given in Table 2. The experimental design war a randomized complete block with four replications.

Fertilizer amounts $\left(\mathrm{kg} \mathrm{ha}^{-1}\right)$ subsequently surface applied were $38 \mathrm{~N}$ in 1994; $97 \mathrm{~N}, 99 \mathrm{P}$, and $221 \mathrm{~K}$ in $1995 ; 237 \mathrm{~N}, 28 \mathrm{P}$, and $54 \mathrm{~K}$ in 1996; and $223 \mathrm{~N}, 59 \mathrm{P}$, and $112 \mathrm{~K}$ in 1997. Nutrient sources used were $\mathrm{NH}_{4} \mathrm{NO}_{3}, \mathrm{KCl}$, triple superphosphate, and 19-19-19,0-25-25, and 5-20-20 fertilizers. The check plots received only NPK fertilizer.

In April 1994, the area was rotary mowed and then sod-seeded with orchardgrass (Dactylis glomerata cv. Potomac) at $8.7 \mathrm{~kg} \mathrm{ha}^{-1}$, Kentucky bluegrass (Poa pratense cv. Canvy) at $3 \mathrm{~kg} \mathrm{ha}^{-1}$, and tall fescue (Festuca arundinacea cv. KY31) at $10.9 \mathrm{~kg} \mathrm{ha}^{-1}$ using a Brillion seeder (Brillion Iron Works, Inc., Brillion, WI) to simulate frost seeding. Because these species did not establish well, the area was reseeded July 1994 with a no-till pasture renovator using rates of $13.4 \mathrm{~kg} \mathrm{ha}^{-1}$ orchardgrass (cv. Abel), $10.5 \mathrm{~kg} \mathrm{ha}^{-1} \mathrm{KY} 31$ tall fescue, and $4.3 \mathrm{~kg} \mathrm{ha}{ }^{-1}$ Canvy bluegrass. To improve stands, another

${ }^{1}$ The mention of trade or manufacturer names is made for information only and does not imply an endorsement, recommendation, or exclusion by USDA-ARS. 
Table 2. Chemical properties of amendments

\begin{tabular}{lcccccc}
\hline & \multicolumn{5}{c}{$\mathrm{CaCO}_{3}$} \\
Amendment & $\begin{array}{c}\mathrm{Ca} \\
\left(\mathrm{g} \mathrm{kg}^{-1}\right)\end{array}$ & $\begin{array}{c}\mathrm{Mg} \\
\left(\mathrm{g} \mathrm{kg}^{-1}\right)\end{array}$ & $\begin{array}{c}\mathrm{S} \\
\left(\mathrm{g} \mathrm{kg}^{-1}\right)\end{array}$ & $\begin{array}{c}\text { equivalent } \mathrm{g} \\
\text { per } 100 \mathrm{~g} \text { soil }\end{array}$ & $\begin{array}{c}\mathrm{pH}(1: 1 \\
\text { water })\end{array}$ & $\begin{array}{c}\mathrm{EC}(1: 1 \text { water }) \\
\left(\mathrm{dS} \mathrm{m}^{-1}\right)\end{array}$ \\
\hline DL & 210 & 110 & 0 & 104 & 8.9 & 0.03 \\
MgO & 0 & 510 & 0 & 245 & - & - \\
FGD-22 & 238 & 0.23 & 216 & 5 & 8.9 & 1.67 \\
FBC-26 & 414 & 3.65 & 174 & 55 & 12.4 & 6.18 \\
\hline
\end{tabular}

Note: From Clark et al. (1995) and Ritchey and Snuffer (2002).

seeding was made in February 1995 with $19.7 \mathrm{~kg} \mathrm{ha}^{-1}$ Abel orchardgrass and $20.9 \mathrm{~kg} \mathrm{ha}^{-1} \mathrm{KY} 31$ tall fescue, and in March 1995 with $14.1 \mathrm{~kg} \mathrm{ha}^{-1}$ Canvy bluegrass. Because the stand was still poor, dicamba (dimethylamine salt of 2-methoxy-3, 6-dichloro-0-anisic acid) herbicide was applied on May 24 and July 10, 1995 at 7.0 liter $\mathrm{ha}^{-1}$ to reduce broadleaf growth.

As described in Ritchey, Belesky, and Halvorson (2004), the $8 \times 3 \mathrm{~m}$ plots were subdivided into three equal $2.7-\mathrm{m}$-wide subplots in early spring 1998 for seeding clovers into the experiments as 1) no additional planting, 2) red clover (Trifolium pratense cv. Cinnamon), and 3) white clover (Trifolium repens cv. Huia). Surface applications of 0-25-25 fertilizer to supply $112 \mathrm{~kg} \mathrm{ha}^{-1} \mathrm{P}$ and $213 \mathrm{~kg} \mathrm{ha}^{-1} \mathrm{~K}$ were made in April 1998 and April 1999.

Soil samples for chemical analyses were collected from 0 - to $15-\mathrm{cm}$ and $15-$ to $30 \mathrm{~cm}$ depths of each plot using a $2.5-\mathrm{cm}$-diam. soil sampler in either August or September of 1994 through 1997. In August 1999, similar samples were collected from the 0-to 2.5-, 2.5- to 5.0-, 5- to 10-, and 10- to 15-cm depths. In September of 1999, three polyvinyl chloride (PVC) sampling tubes $5 \mathrm{~cm}$ in diameter were driven into the soil in each plot using a specially designed attachment to the hydraulic power system on a tractor. The soil-filled tubes were removed, taken to the workshop, and cut into appropriate depth increments to determine treatment effects on soil physical properties at various soil depths. One set of tube samples was cut into $5-\mathrm{cm}$ depth intervals. Dry bulk density and $\mathrm{K}_{\text {sat }}$ determined in these samples. The second set of tube samples were cut into $2.5-\mathrm{cm}$ depth intervals and used to determine PAW. In addition, four tube samples were taken in each replication of the experimental field. These were cut into 0- to 5-, 5- to 10-, 10- to 15-, 15to 22.5-, 22.5- to 30-, and 30- to 45-cm intervals for particle size analysis using the pipette method (Gee and Bauder 1986).

Yield was evaluated by clipping a $4.3 \mathrm{~m}^{2}$ (in 1994 to 1997) or $1.6 \mathrm{~m}^{2}$ (in 1998 and 1999) area in the center of the subplots at the 5-cm height. Forage dry matter percentages were determined from oven-dried samples. Plant mineral analyses were conducted as described (Ritchey and Snuffer 2002). 
A 1:1 (w:w) suspension of soil with $0.01 \mathrm{M} \mathrm{CaCl}_{2}$ was used to measure $\mathrm{pH}$. Exchangeable $\mathrm{Ca}, \mathrm{Mg}$, and $\mathrm{S}$ were measured in an extract with neutral $1 \mathrm{M} \mathrm{NH}_{4} \mathrm{Oac}$ (Thomas 1982). An estimate of nonexchangeable $\mathrm{Ca}, \mathrm{Mg}$, and $\mathrm{S}$ was obtained by shaking soil with $0.1 \mathrm{M} \mathrm{HCl}$ at 1 soil:20 $\mathrm{HCl}$ ratio for $36 \mathrm{~h}$. Aluminum was measured in $1 \mathrm{M} \mathrm{KCl}$ extracts (Barnhisel and Bertsch 1982). Elemental analyses were conducted by inductively coupled plasma emission spectroscopy (SpectroFlame Modula Tabletop ICP, Spectro Analytical Instruments, Inc.).

$\mathrm{K}_{\text {sat }}$ was determined using the constant head method (Klute 1967a). The soil cores were saturated for at least $24 \mathrm{~h}$ prior to measurement. A constant head level of $20 \mathrm{~cm}$ was applied, and the core was allowed to drain freely until a steady discharge rate was observed at the outlet. Hydraulic conductivity of samples were recorded as zero if no discharge was observed $30 \mathrm{~min}$ after the head was applied. After steady flow was achieved, the $\mathrm{K}_{\text {sat }}$ was calculated using Darcy's law as $\mathrm{K}_{\mathrm{sat}}=(\mathrm{Q} / \mathrm{At})(\mathrm{L} / \Delta \mathrm{H})$ where $\mathrm{Q}$ is the discharge volume of effluent $\left(\mathrm{cm}^{3}\right)$ obtained in time $t$ hours; A is the cross-sectional area of the sample, $\mathrm{L}$ is the length of the sample, and $\Delta \mathrm{H}$ is the hydraulic head difference. Bulk density was determined on the same core sample used to measure hydraulic conductivity (Blake 1967).

Water retentions at tensions of 0.03 and $1.5 \mathrm{MPa}(1 / 3$ and 15 bars) were determined on the 2.5 -cm-long soil cores using a membrane-measuring method (Klute 1967b). The soil core and pressure plates were saturated for $12 \mathrm{~h}$ before placing them into the pressure chamber. Samples were allowed to equilibrate, and the volumetric water content at each pressure was determined by weighing. The differences between the volumetric water contents at 0.03 and $1.5 \mathrm{MPa}$ taken as PAW.

Analysis of variance of the soil physical and chemical data was performed using the procedures in the general linear model of SAS (1990). Least significant difference (LSD) was used to separate means $(\mathrm{P}>0.05)$.

\section{RESULTS AND DISCUSSION}

\section{Upper Profile Changes over Time and over Small Depth Increments}

Results of particle size analysis (Table 3) showed that coarse and medium sand and silt fractions dominated the soil texture for the experimental field. The USDA textural grouping was a silt loam for all depths. As would be expected, the coarser fractions (sands and coarse silt) decreased and the finer fractions increased with depth. However, coarser fractions apparently reached a minimum, and correspondingly, finer fractions reached a maximum at the 22.5- to $30-\mathrm{cm}$ depth.

Tables 4 and 5 summarize the effects of application of the amendments on soil $\mathrm{pH}$ and exchangeable $\mathrm{Ca}, \mathrm{Mg}, \mathrm{Al}$, and $\mathrm{S}$ in the 0- to $15-\mathrm{cm}$ and 15- to 30cm depth samples taken from 1994 though 1997. In addition, means of the 
Table 3. Soil texture of experimental plots (USDA classification)

\begin{tabular}{lrrcccc}
\hline \multirow{2}{*}{$\begin{array}{l}\text { Size } \\
\text { fraction }\end{array}$} & $0-5 \mathrm{~cm}$ & $5-10 \mathrm{~cm}$ & $10-15 \mathrm{~cm}$ & $15-22.5 \mathrm{~cm}$ & $22.5-30 \mathrm{~cm}$ & $30-45 \mathrm{~cm}$ \\
\cline { 2 - 6 } & \multicolumn{5}{c}{ \% Size fraction for depth interval } \\
\hline VCS & 2.9 & 3.5 & 1.5 & 1.8 & 2.1 & 3.2 \\
CS & 13.7 & 7.0 & 5.3 & 2.9 & 2.7 & 6.9 \\
MS & 12.7 & 5.6 & 4.3 & 2.5 & 2.0 & 5.2 \\
FS & 8.7 & 4.3 & 3.3 & 2.6 & 2.2 & 4.2 \\
VFS & 6.5 & 4.6 & 4.6 & 3.4 & 4.8 & 6.0 \\
Total & 44.5 & 24.7 & 19.0 & 13.2 & 13.8 & 25.3 \\
sand & & & & & 14.5 & 15.6 \\
CSi & 12.5 & 14.9 & 10.5 & 12.2 & 30.4 & 29.8 \\
MSi & 27.3 & 36.9 & 38.6 & 36.0 & 18.1 & 11.3 \\
FSi & 9.1 & 12.8 & 17.3 & 15.6 & 63.1 & 56.7 \\
Total slit & 48.8 & 64.5 & 66.4 & 63.8 & 23.1 & 18.0 \\
Clay & 6.7 & 10.9 & 14.7 & 23.0 & \\
\hline
\end{tabular}

Note: VCS, very coarse sand; CS, coarse sand; MS, medium sand; FS, fine sand; VFS, very fine sand; CSi, coarse silt; MSi, medium silt; FSi, fine silt.

Values represent mean of four replications.

values for samples taken over the four small depth increments in 1999 (Table 6) were calculated, taking into account bulk density of each layer (included in Table 4) for comparison with values reported for the 0- to 15-cm depth samples taken over time from 1994 through 1997.

These data indicate that application of the amendments generally increased soil $\mathrm{pH}$, that the increases tended to be proportional to the total $\mathrm{Ca}+\mathrm{Mg}$ and total neutralizing equivalent (TNE) of amendments applied per unit area (Table 1), that their effect persisted over time, and that the increases were more pronounced in the 0 - to $15-\mathrm{cm}$ depth interval. This last effect is illustrated by the following examples. The treatment with $526 \mathrm{~kg} \mathrm{ha}^{-1} \mathrm{MgO}$ applied alone (treatment $\mathrm{MgO}$ ) increased $\mathrm{pH}$ in the $0-$ to $15-\mathrm{cm}$ depth interval by about 0.2 to 0.3 units over time but had a negligible effect in the $15-$ to $30-\mathrm{cm}$ depth. The application of $15,000 \mathrm{~kg} \mathrm{ha}^{-1} \mathrm{FBC}$ in combination with $\mathrm{MgO}$ produced a large $\mathrm{pH}$ increase in the 0 - to $15-\mathrm{cm}$ depth (about 1.2 to $1.7 \mathrm{pH}$ units) but only about 0.1 to $0.2 \mathrm{pH}$ units in the 15 - to $30-\mathrm{cm}$ depth.

These effects on $\mathrm{pH}$ were inversely mirrored in the effects on exchangeable Al. Exchangeable Al concentrations decreased the most in the $\mathrm{FBC}+\mathrm{MgO}$ application and the least when $\mathrm{MgO}$ was applied alone. The levels of exchangeable $\mathrm{Al}$ were lower in the $0-$ to $15-\mathrm{cm}$ compared to the 15- to 30-cm depth interval. Interestingly, although the total $\mathrm{Ca}+\mathrm{Mg}$ applied with the $4650 \mathrm{~kg} \mathrm{ha}^{-1}$ DL was almost three times less than the total applied with the $16,000 \mathrm{~kg} \mathrm{ha}^{-1} \mathrm{FGD}+526 \mathrm{~kg} \mathrm{ha}^{-1} \mathrm{MgO}$, the decreases in exchangeable $\mathrm{Al}$ were similar. This indicated that the increase in $\mathrm{pH}$ and depression of exchangeable $\mathrm{Al}$ did not depend entirely on the total amounts 
Table 4. Treatment effects over time on soil profile $\mathrm{pH}$ and $\mathrm{Ca}, \mathrm{Mg}, \mathrm{Al}$, and $\mathrm{S}$ recovered in $\mathrm{CEC}$ extracts from 0- to 15-cm depth samples

\begin{tabular}{|c|c|c|c|c|c|c|c|c|}
\hline Property & Year & Check & DL & $\mathrm{MgO}$ & FGD + DL & $\mathrm{FGD}+\mathrm{MgO}$ & $\mathrm{FBC}+\mathrm{MgO}$ & $\mathrm{LSD}_{0.05}$ \\
\hline \multirow{6}{*}{$\mathrm{pH}$} & 1994 & 3.90 & 4.39 & 4.09 & 4.40 & 4.37 & 5.11 & 0.24 \\
\hline & 1995 & 3.81 & 4.27 & 4.10 & 4.42 & 7.22 & 5.09 & 0.18 \\
\hline & 1996 & 4.03 & 4.52 & 4.20 & 4.64 & 4.38 & 5.05 & 0.19 \\
\hline & 1997 & 3.87 & 4.49 & 4.09 & 4.60 & 4.34 & 5.53 & 0.33 \\
\hline & $\mathrm{LSD}_{0.05}$ & 0.11 & 0.14 & 0.13 & 0.29 & 0.15 & 0.41 & \\
\hline & & \multicolumn{7}{|c|}{$\mathrm{cmol}_{\mathrm{c}} \mathrm{kg}^{-1}$ soil } \\
\hline \multirow[t]{5}{*}{$\mathrm{Ca}$} & 1994 & 1.15 & 2.36 & 1.03 & 9.03 & 3.81 & 11.49 & 2.15 \\
\hline & 1995 & 1.21 & 2.39 & 1.13 & 5.36 & 3.93 & 11.71 & 3.10 \\
\hline & 1996 & 1.11 & 2.63 & 0.89 & 3.60 & 3.09 & 7.27 & 1.01 \\
\hline & 1997 & 1.12 & 2.61 & 1.16 & 3.83 & 2.83 & 10.84 & 2.87 \\
\hline & $\mathrm{LSD}_{0.05}$ & 0.15 & 0.69 & 0.29 & 2.51 & 0.68 & 5.38 & \\
\hline \multirow[t]{5}{*}{$\mathrm{Mg}$} & 1994 & 0.28 & 1.22 & 0.75 & 0.37 & 0.90 & 0.28 & 0.41 \\
\hline & 1995 & 0.26 & 1.20 & 1.27 & 0.57 & 0.35 & 0.39 & 0.25 \\
\hline & 1996 & 0.20 & 1.12 & 0.93 & 0.65 & 0.79 & 0.26 & 0.27 \\
\hline & 1997 & 0.17 & 1.02 & 1.00 & 0.67 & 0.71 & 0.30 & 0.25 \\
\hline & $\mathrm{LSD}_{0.05}$ & 0.04 & 0.44 & 0.26 & 0.20 & 0.34 & 0.16 & \\
\hline \multirow[t]{5}{*}{$\mathrm{Al}$} & 1994 & 2.77 & 1.72 & 2.23 & 1.13 & 1.87 & 0.51 & 0.78 \\
\hline & 1995 & 2.77 & 1.41 & 2.14 & 1.14 & 1.51 & 0.25 & 0.69 \\
\hline & 1996 & 2.35 & 1.29 & 2.00 & 0.83 & 1.34 & 0.26 & 0.55 \\
\hline & 1997 & 3.09 & 1.43 & 2.59 & 1.10 & 1.63 & 0.20 & 0.60 \\
\hline & $\mathrm{LSD}_{0.05}$ & 0.37 & 0.67 & 0.49 & 0.37 & 0.93 & 0.38 & \\
\hline \multirow[t]{5}{*}{ S } & 1994 & 0.38 & 0.40 & 0.37 & 5.86 & 3.22 & 3.37 & 2.31 \\
\hline & 1995 & 0.35 & 0.36 & 0.33 & 1.68 & 1.22 & 2.71 & 0.90 \\
\hline & 1996 & 0.30 & 0.36 & 0.31 & 0.64 & 0.73 & 1.21 & 0.14 \\
\hline & 1997 & 0.25 & 0.29 & 0.32 & 0.45 & 0.48 & 0.89 & 0.31 \\
\hline & $\mathrm{LSD}_{0.05}$ & 0.05 & 0.04 & 0.13 & 2.50 & 1.74 & 1.20 & \\
\hline
\end{tabular}


Table 5. Treatment effects over time on soil profile $\mathrm{pH}$ and $\mathrm{Ca}, \mathrm{Mg}, \mathrm{Al}$, and $\mathrm{S}$ recovered in CEC extracts from 15- to 30-cm depth samples

\begin{tabular}{|c|c|c|c|c|c|c|c|c|}
\hline Property & Year & Check & DL & $\mathrm{MgO}$ & $\mathrm{FGD}+\mathrm{DL}$ & $\mathrm{FGD}+\mathrm{MgO}$ & $\mathrm{FBC}+\mathrm{MgO}$ & $\mathrm{LSD}_{0.05}$ \\
\hline & 1994 & 3.83 & 3.99 & 3.89 & 4.11 & 4.12 & 4.06 & 0.12 \\
\hline & 1995 & 3.75 & 3.82 & 3.81 & 3.92 & 3.96 & 3.91 & 0.08 \\
\hline & 1996 & 3.91 & 3.91 & 3.98 & 4.04 & 4.07 & 4.01 & 0.12 \\
\hline & 1997 & 3.83 & 3.90 & 3.87 & 3.99 & 4.01 & 3.95 & 0.09 \\
\hline & $\operatorname{LSD}_{0.05}$ & 0.15 & 0.11 & 0.13 & 0.14 & 0.12 & 0.08 & \\
\hline & & & & & $\left(\mathrm{cmol}_{\mathrm{c}} \mathrm{k}\right.$ & & & \\
\hline \multirow[t]{5}{*}{$\mathrm{Ca}$} & 1994 & 0.59 & 0.72 & 0.54 & 2.55 & 2.27 & 2.95 & 1.09 \\
\hline & 1995 & 0.68 & 0.61 & 0.64 & 2.17 & 2.00 & 1.69 & 0.51 \\
\hline & 1996 & 0.63 & 0.62 & 0.60 & 1.71 & 1.56 & 1.45 & 0.28 \\
\hline & 1997 & 0.59 & 0.79 & 0.61 & 1.53 & 1.42 & 1.53 & 0.51 \\
\hline & $\mathrm{LSD}_{0.05}$ & 0.17 & 0.34 & 0.15 & 0.32 & 0.2 & 1.31 & \\
\hline \multirow[t]{5}{*}{$\mathrm{Mg}$} & 1994 & 0.14 & 0.28 & 0.25 & 0.14 & 0.26 & 0.18 & 0.13 \\
\hline & 1995 & 0.17 & 0.23 & 0.24 & 0.12 & 0.11 & 0.15 & 0.08 \\
\hline & 1996 & 0.14 & 0.21 & 0.23 & 0.08 & 0.08 & 0.11 & 0.04 \\
\hline & 1997 & 0.13 & 0.19 & 0.25 & 0.08 & 0.08 & 0.08 & 0.05 \\
\hline & $\mathrm{LSD}_{0.05}$ & 0.05 & 0.05 & 0.09 & 0.03 & 0.15 & 0.05 & \\
\hline \multirow[t]{5}{*}{$\mathrm{Al}$} & 1994 & 4.09 & 4.00 & 3.94 & 3.23 & 3.59 & 3.53 & 0.75 \\
\hline & 1995 & 4.45 & 3.86 & 4.19 & 3.87 & 3.01 & 3.96 & 0.63 \\
\hline & 1996 & 3.69 & 3.41 & 3.43 & 3.01 & 2.66 & 3.23 & 0.68 \\
\hline & 1997 & 3.96 & 3.88 & 3.97 & 3.61 & 3.14 & 3.58 & 0.68 \\
\hline & $\operatorname{LSD}_{0.05}$ & 0.26 & 0.54 & 0.49 & 0.47 & 1.24 & 0.66 & \\
\hline \multirow[t]{5}{*}{ S } & 1994 & 0.51 & 0.53 & 0.55 & 2.07 & 1.81 & 1.75 & 0.53 \\
\hline & 1995 & 0.53 & 0.53 & 0.49 & 1.71 & 1.48 & 1.10 & 0.33 \\
\hline & 1996 & 0.53 & 0.59 & 0.51 & 1.19 & 1.13 & 1.14 & 0.26 \\
\hline & 1997 & 0.47 & 0.52 & 0.44 & 0.99 & 0.96 & 0.97 & 0.17 \\
\hline & $\mathrm{LSD}_{0.05}$ & 0.11 & 0.12 & 0.09 & 0.25 & 0.13 & 0.71 & \\
\hline
\end{tabular}


Table 6. Treatment effects on soil profile $\mathrm{pH}$ and $\mathrm{Ca}, \mathrm{Mg}, \mathrm{Al}$, and $\mathrm{S}$ recovered in CEC extract on small increment samples taken in 1999

\begin{tabular}{|c|c|c|c|c|c|c|c|c|}
\hline Property & Depth $(\mathrm{cm})$ & Check & DL & $\mathrm{MgO}$ & $\mathrm{FGD}+\mathrm{DL}$ & $\mathrm{FGD}+\mathrm{MgO}$ & $\mathrm{FBC}+\mathrm{MgO}$ & $\mathrm{LSD}_{0.05}$ \\
\hline \multirow[t]{5}{*}{$\mathrm{pH}$} & $0-2.5$ & 4.0 & 5.2 & 4.4 & 5.3 & 4.6 & 6.0 & 0.3 \\
\hline & $2.5-5$ & 3.9 & 4.3 & 4.1 & 4.5 & 4.3 & 5.2 & 0.3 \\
\hline & $5-10$ & 3.9 & 4.1 & 4.1 & 4.3 & 4.1 & 4.4 & 0.2 \\
\hline & $10-15$ & 3.9 & 4.1 & 4.1 & 4.2 & 4.2 & 4.2 & 0.2 \\
\hline & \multicolumn{8}{|c|}{$\left(\mathrm{cmol}_{\mathrm{c}} \mathrm{kg}^{-1}\right.$ soil $)$} \\
\hline \multirow[t]{4}{*}{$\mathrm{Ca}$} & $0-2.5$ & 2.24 & 6.56 & 3.59 & 8.98 & 4.90 & 12.76 & 3.21 \\
\hline & $2.5-5$ & 0.72 & 1.64 & 1.28 & 3.28 & 1.84 & 5.16 & 1.75 \\
\hline & $5-10$ & 0.46 & 0.64 & 0.50 & 1.76 & 1.04 & 1.76 & 0.91 \\
\hline & $10-15$ & 0.36 & 0.48 & 0.44 & 1.32 & 0.78 & 1.27 & 0.50 \\
\hline \multirow[t]{4}{*}{$\mathrm{Mg}$} & $0-2.5$ & 0.35 & 1.41 & 1.19 & 1.26 & 1.12 & 0.41 & 0.46 \\
\hline & $2.5-5$ & 0.13 & 0.58 & 0.63 & 0.47 & 0.42 & 0.17 & 0.19 \\
\hline & $5-10$ & 0.08 & 0.32 & 0.36 & 0.22 & 0.22 & 0.07 & 0.13 \\
\hline & $10-15$ & 0.07 & 0.27 & 0.37 & 0.14 & 0.15 & 0.05 & 0.11 \\
\hline \multirow[t]{4}{*}{$\mathrm{Al}$} & $0-2.5$ & 2.00 & 0.13 & 0.82 & 0.30 & 0.55 & 0.11 & 0.58 \\
\hline & $2.5-5$ & 3.10 & 1.91 & 2.14 & 1.32 & 1.66 & 0.24 & 1.00 \\
\hline & $5-10$ & 3.12 & 2.85 & 2.76 & 2.25 & 2.46 & 2.09 & 0.95 \\
\hline & $10-15$ & 3.22 & 3.25 & 3.09 & 2.59 & 2.79 & 3.00 & 0.79 \\
\hline \multirow[t]{4}{*}{$\mathrm{S}$} & $0-2.5$ & 0.19 & 0.07 & 0.13 & 0.09 & 0.11 & 0.17 & 0.06 \\
\hline & $2.5-5$ & 0.21 & 0.15 & 0.19 & 0.15 & 0.17 & 0.13 & 0.08 \\
\hline & $5-10$ & 0.22 & 0.21 & 0.19 & 0.28 & 0.29 & 0.31 & 0.06 \\
\hline & $10-15$ & 0.28 & 0.27 & 0.30 & 0.40 & 0.43 & 0.42 & 0.12 \\
\hline
\end{tabular}


of $\mathrm{Ca}+\mathrm{Mg}$ but upon the source. The DL amendment is high in carbonates, $\mathrm{MgO}$ is high in oxides, and FBCs contain carbonate, oxide, and hydroxide. These anions are capable of neutralizing acidity. On the other hand, gypsum contains mainly sulfate, which has essentially no ability to neutralize acidity. The total neutralizing equivalent of the amendments is based on the anions present and thus is high for amendments with oxides and carbonate and zero for Ca sulfate. Accordingly, the change in mean $\mathrm{pH}$ for 0 - to 15$\mathrm{cm}$ for 1994 through 1997 was more closely related to amendment TNE $\left(r^{2}=0.95, P=0.001, n=6\right)$ than to amendment total $\mathrm{Ca}+\mathrm{Mg}\left(\mathrm{r}^{2}=0.74\right.$, $\mathrm{P}=0.03, \mathrm{n}=6$ ).

The greater effects of the applied amendments on upper profile soil $\mathrm{pH}$ and exchangeable $\mathrm{Al}$ compared to the 15- to 30-cm layers indicated that effects of the amendments were relatively immobile. This was supported by the ratios given in Table 7, which indicates that the amounts of exchangeable cations tended to be several times higher in the $0-$ to $15-\mathrm{cm}$ than in the $15-$ to $30-\mathrm{cm}$ depth interval (Table 7). Nevertheless, some movement of both elements to the deeper depth did occur because exchangeable $\mathrm{Ca}$ and $\mathrm{Mg}$ in the 15- to $30-\mathrm{cm}$ depth interval were generally higher than the corresponding values in the check plots (Table 5). The behavior of this downward movement over time varied with the source. For example, the exchangeable Ca levels in both depth intervals tended in decrease over time in the treatments receiving gypsum (FGD $+\mathrm{DL}$ and $\mathrm{FGD}+\mathrm{MgO}$ ), indicating that $\mathrm{Ca}$ was being lost from both layers (Tables 4 and 5). Magnesium in the 15- to 30-cm depth also tended in decrease in all the CCBP amendment treatments. On the other hand, the $\mathrm{Ca}$ and $\mathrm{Mg}$ contents in both layers were almost unchanged over time in the DL treatment (Tables 4 and 5), which indicated the low solubility and mobility of the limestone used in this experiment. In fact, the Ca level in the 15- to 30-cm layer for DL treatment was very close to the check (Table 5).

The reason for the behavior of exchangeable $\mathrm{Ca}$ and to a lesser extent $\mathrm{Mg}$ over time in the CCBP amendment treatments was probably due to the mobility induced by $\mathrm{S}$ applied with the CCBP amendments. For these

Table 7. Ratios of $\mathrm{Ca}$ and $\mathrm{Mg}$ in 0 - to $15-\mathrm{cm}$ layer to those in 15- to 30-cm layer

\begin{tabular}{lccccccc}
\hline Property & Year & Check & DL & MgO & $\begin{array}{c}\text { FGD }+ \\
\text { DL }\end{array}$ & $\begin{array}{c}\text { FGD }+ \\
\text { MgO }\end{array}$ & $\begin{array}{c}\text { FBC }+ \\
\text { MgO }\end{array}$ \\
\hline Ca & 1994 & 1.95 & 3.28 & 1.91 & 3.54 & 1.68 & 3.89 \\
& 1995 & 1.78 & 3.92 & 1.77 & 2.47 & 1.97 & 6.93 \\
& 1996 & 1.76 & 4.24 & 1.48 & 2.11 & 1.98 & 5.01 \\
$\mathrm{Mg}$ & 1997 & 1.90 & 3.30 & 1.90 & 2.50 & 1.99 & 7.08 \\
& 1994 & 2.00 & 4.36 & 3.00 & 2.64 & 3.46 & 1.56 \\
& 1995 & 1.53 & 5.22 & 5.29 & 4.75 & 3.18 & 2.60 \\
& 1996 & 1.43 & 5.33 & 4.04 & 8.13 & 9.88 & 2.36 \\
& 1997 & 1.31 & 5.37 & 4.00 & 8.38 & 8.88 & 3.75 \\
\hline
\end{tabular}


treatments, the $\mathrm{S}$ recovered in the CEC extract decreased over time in the 0 - to 15-cm depth interval, indicating downward movement (Table 4). The S levels in the 15- to $30-\mathrm{cm}$ depth interval for the CCBP amended plots were higher than the corresponding values for the check plots (Table 5), supporting the idea that $\mathrm{S}$ was being leached from the profile. The decrease in $\mathrm{S}$ over time was mirrored in similar decreases in exchangeable $\mathrm{Ca}$. It is possible that $\mathrm{S}$ formed ion pairs with the $\mathrm{Ca}$ that enhanced its downward movement.

It would appear that the dissolution and movement of $\mathrm{S}$ depended on the form in which it was applied. For example, the $\mathrm{S}$ recovered in the CEC extract for 1994 in the 0- to 15-cm depth interval (Table 4) was about two times higher for the FGD + DL compared to the FGD + MgO application even though the amount of S applied as FGD was the same (345.6 $\mathrm{g} \mathrm{m}^{-2}$ ) (Table 1). Although $\mathrm{S}$ was applied at a lower rate $\left(239 \mathrm{~g} \mathrm{~m}^{-2}\right)$ with the $\mathrm{FBC}+\mathrm{MgO}$ (Table 1$)$, the $\mathrm{S}$ extracted for 1994 in the 0 - to $15-\mathrm{cm}$ depth was about the same as that for the FGD + MgO amendment.

Similar results as for the previous years are summarized in Table 6 for the small depth increment samples taken in 1999. These results revealed greater detail of the effect of the amendments on $\mathrm{pH}$ and exchangeable $\mathrm{Ca}, \mathrm{Mg}, \mathrm{Al}$, and $\mathrm{S}$ in the 0 - to $15-\mathrm{cm}$ depth interval than those obtained from the single sampling over this depth. For comparison, values for check, DL, and FBC $+\mathrm{MgO}$ (Ritchey, Belesky, and Halvorson 2004) are presented. The most interesting finding from these more detailed samplings was that most of the treatment effects were restricted to the $0-$ to $2.5-\mathrm{cm}$ and $2.5-$ to $5-\mathrm{cm}$ depths, as discussed (Ritchey, Belesky, and Halvorson 2004). These results provided more clear evidence of the expected reciprocal effect of $\mathrm{pH}$ and exchangeable $\mathrm{Al}$ brought out in the foregoing discussion. In addition, the differential effects of the source of the amendments on exchangeable $\mathrm{Ca}$, $\mathrm{Mg}$, and $\mathrm{S}$ and their downward movement in the upper profile were more clearly defined.

These results for the more detailed sampling of the 0 - to $15-\mathrm{cm}$ profile depth showed that amendment effects on soil $\mathrm{pH}$ were most obvious in the 0 - to $2.5-\mathrm{cm}$ profile depth and decreased in extent with increasing depth (Table 7). The extent of $\mathrm{pH}$ increase in the 0 - to 2.5 -cm layer was positively correlated with total Ca carbonate equivalent (TNE) of the amendments added $\left(r^{2}=0.99\right)$.

Because most of the effects of applying the amendments were concentrated in the $0-$ to $15-\mathrm{cm}$ depth interval and primarily in the $0-$ to $2.5-\mathrm{cm}$ layer, the results of Table 7 were used to calculate the exchangeable $\mathrm{Ca}$, $\mathrm{Mg}$, and $\mathrm{S}$ recovered in the CEC extract $\left(\mathrm{g} \mathrm{m}^{-2}\right)$ in excess of the values in the check plots (termed the net increase) for the 0- to 2.5-, 2.5- to 5-, 5- to $10-$, and 10- to $15-\mathrm{cm}$ depth intervals. The resulting values were considered as the net effect of the treatments on exchangeable $\mathrm{Ca}, \mathrm{Mg}$, and $\mathrm{S}$ that resulted from the application of the amendments. The total net effect ( $\mathrm{g}$ $\mathrm{m}^{-2}$ ) was obtained by summing the net values over the individual 0 - to 15 $\mathrm{cm}$ depth intervals weighted by bulk density. 
Table 8. Amount of $\mathrm{Ca}, \mathrm{Mg}$, and $\mathrm{S}\left(\mathrm{g} \mathrm{m}^{-2}\right)$ recovered in $\mathrm{CEC}$ extracts on 1999 samples less the amounts found in check plots

\begin{tabular}{lcrrrrrr}
\hline \multirow{2}{*}{ Element } & $\begin{array}{c}\text { Depth } \\
\text { (in) }\end{array}$ & \multicolumn{1}{c}{ DL } & MgO & $\begin{array}{c}\text { FGD }+ \\
\text { DL }\end{array}$ & $\begin{array}{r}\text { FGD }+ \\
\text { MgO }\end{array}$ & $\begin{array}{r}\text { FBC }+ \\
\text { MgO }\end{array}$ & LSD $_{0.05}$ \\
\hline \multirow{2}{*}{ a } & $0-2.5$ & 23.56 & 8.91 & 37.44 & 16.14 & 65.02 & 20.71 \\
& $2.5-5$ & 4.72 & 3.43 & 13.96 & 6.78 & 27.13 & 11.25 \\
& $5-10$ & 2.40 & 0.50 & 18.30 & 7.94 & 18.96 & 14.54 \\
& $10-15$ & 1.46 & 1.04 & 14.88 & 5.74 & 12.88 & 8.50 \\
& Integral & 32.14 & 13.88 & 84.58 & 36.6 & 123.99 & 50.60 \\
$\mathrm{Mg}$ & $0-2.5$ & 3.50 & 3.16 & 3.04 & 2.79 & 0.29 & 1.82 \\
& $2.5-5$ & 1.49 & 1.85 & 1.13 & 1.04 & 0.19 & 0.72 \\
& $5-10$ & 2.06 & 2.36 & 1.26 & 1.18 & -0.04 & 1.22 \\
& $10-15$ & 1.78 & 2.74 & 0.72 & 0.70 & -0.18 & 1.16 \\
& Integral & 8.83 & 10.11 & 6.15 & 5.71 & 0.26 & 4.48 \\
$\mathrm{~S}$ & $0-2.5$ & -0.55 & -0.22 & -0.47 & -0.35 & -0.02 & 0.31 \\
& $2.5-5$ & -0.26 & -0.03 & -0.25 & -0.13 & -0.31 & 0.39 \\
& $5-10$ & -0.22 & -0.40 & 0.66 & 0.76 & 1.08 & 0.74 \\
& $10-15$ & -0.28 & 0.20 & 1.46 & 1.62 & 1.46 & 1.70 \\
& Integral & -1.31 & -0.45 & 1.40 & 1.90 & 2.21 & 2.97 \\
\hline
\end{tabular}

Note: For comparison, values for FGD + MgO and DL, as calculated from Ritchey et al. (2004), are given.

The results (Table 8) confirmed that most of the amendment effects on exchangeable $\mathrm{Ca}$ was concentrated in the upper 0- to 5-cm depth. In the DL and $\mathrm{MgO}$ treatments, the $0-$ to $5-\mathrm{cm}$ layers accounted for close to $90 \%$ of the net total increase in exchangeable $\mathrm{Ca}$ for the 0 - to $15-\mathrm{cm}$ depth. Previous research also showed that residual limestone from surface applications tended to be found as an unreactive thin layer at the soil surface with major presence in the 0-2-cm depth (Allen and Hossner 1991). The net total increase in exchangeable $\mathrm{Ca}(0-$ to $15-\mathrm{cm}$ layer $)$ for the DL treatment was only about $30 \%$ of the total $98 \mathrm{~g} \mathrm{~m}^{-2}$ applied. It would appear that most of the $\mathrm{Ca}$ applied with calcitic dolomite limestone did not significantly influence the amount adsorbed on the soil exchange. The reason for this may be that the $\mathrm{CaCO}_{3}$ moiety of calcitic dolomite limestone was sparingly soluble, given that the solubility product of pure $\mathrm{CaCO}_{3}$ is $4.96 \times 10^{-9}$. There was no significant difference of net increase of exchangeable Ca between DL and FGD $+\mathrm{MgO}$ treatments in the 0- to $15-\mathrm{cm}$ depth, although the applied $\mathrm{Ca}$ of the latter was nearly four times greater than that of the former, probably because the high solubility of the gypsum in the $\mathrm{FGD}+\mathrm{MgO}$ treatment resulted in its removal from the profile by leaching.

The net total exchangeable $\mathrm{Mg}$ recovered from the $\mathrm{FBC}+\mathrm{MgO}$ treatment was much lower than that from other treatments (Table 8). This might be explained by the high level of exchangeable $\mathrm{Ca}$ in the 
$\mathrm{FBC}+\mathrm{MgO}$ treatment and competition on the exchange sites between $\mathrm{Ca}$ and $\mathrm{Mg}$ (Table 8). There were no significant differences in exchangeable $\mathrm{Mg}$ among other treatments. In the DL treatment $80 \%$ of the net total exchangeable $\mathrm{Mg}$ recovered was from the $0-$ to $10-\mathrm{cm}$ depth, and the entire $0-$ to $15-$ $\mathrm{cm}$ depth accounted for only $17 \%$ of the total $\mathrm{Mg}$ applied. In contrast, $38 \%$ of the $\mathrm{Mg}$ was recovered in exchangeable form for the $\mathrm{MgO}$ treatment (Tables 1 and 8). The solubility product for pure $\mathrm{MgCO}_{3}$ is $6.82 \times 10^{-6}$, which is evidence that, although still sparingly soluble, the $\mathrm{MgCO}_{3}$ moiety of dolomitic limestone may have been more soluble and therefore more mobile than the $\mathrm{CaCO}_{3}$ moiety. The distribution of exchangeable $\mathrm{Ca}$ and $\mathrm{Mg}$ over the small depth increments in the 0 - to $15-\mathrm{cm}$ portion of the profile tends to support the idea that both exchangeable $\mathrm{Ca}$ and exchangeable $\mathrm{Mg}$ from applied calcitic dolomite tended to be located in the upper layer of the soil profile; the former more so than the latter.

The exchangeable Ca from the CCBP amendments also tended to be found in the upper 0 - to $10-\mathrm{cm}$ depth of the 0 - to $15-\mathrm{cm}$ profile (Table 8 ). The amounts of $\mathrm{Ca}$ applied for the CCBP treatments were in the ratio 4:5:6.5 of FGD + MgO:FGD + DL:FBC + MgO, and the net increases in exchangeable $\mathrm{Ca}$ in the $0-$ to $2.5-\mathrm{cm}$ and $2.5-$ to $5.0-\mathrm{cm}$ depth intervals were significantly higher for the treatments where more $\mathrm{Ca}$ was applied. However, the differences were not significant for the 5- to $10-\mathrm{cm}$ and $10-$ to $15-\mathrm{cm}$ depths. The $0-$ to $10-\mathrm{cm}$ depth accounted for 80 to $90 \%$ of the net total increase of exchangeable $\mathrm{Ca}$ in the top $15 \mathrm{~cm}$ of the profile for the CCBP treatments. On the other hand, the net total increase of exchangeable $\mathrm{Ca}$ in the 0 - to $15-\mathrm{cm}$ depth represented 10,18 , and $20 \%$ of the $\mathrm{Ca}$ applied as $\mathrm{FGD}+\mathrm{MgO}, \mathrm{FGD}+\mathrm{DL}$, and $\mathrm{FBC}+\mathrm{MgO}$, respectively (Tables 1 and 8). In the FGD + DL treatment, 1.25 times more $\mathrm{Ca}$ was applied than in the $\mathrm{FGD}+\mathrm{MgO}$ treatment, but the net total increase in exchangeable $\mathrm{Ca}$ in the 0 - to $15-\mathrm{cm}$ depth was more than doubled. Where more of the $\mathrm{Ca}$ added was in the form of gypsum, which is more soluble, it is reasonable that less of the $\mathrm{Ca}$ was retained in the exchangeable form. The solubility product of pure $\mathrm{CaSO}_{4}$ is $7.10 \times 10^{-5}$, indicating that gypsum is more soluble than either $\mathrm{CaCO}_{3}$ or $\mathrm{MgCO}_{3}$ and could more readily leach from the profile.

The $\mathrm{FBC}+\mathrm{MgO}$ amendment supplied $32 \mathrm{~g} \mathrm{~m}^{-2}$ of $\mathrm{Mg}$ compared to $27 \mathrm{~g} \mathrm{~m}^{-2}$ for the $\mathrm{MgO}$ and $\mathrm{FGD}+\mathrm{MgO}$ applications (Table 1), yet in the $0-$ to $2.5-\mathrm{cm}$ and 2.5- to $5.0-\mathrm{cm}$ depths the net increase in exchangeable $\mathrm{Mg}$ was an order of magnitude less for $\mathrm{FBC}+\mathrm{MgO}\left(0.48 \mathrm{~g} \mathrm{~m}^{-2}\right)$ than the other two treatments $\left(5.01 \mathrm{~g} \mathrm{~m}^{-2}\right.$ and $\left.3.83 \mathrm{~g} \mathrm{~m}^{-2}\right)$ (Table 8$)$. The net increases were almost zero in the 5- to 10 - and $10-$ to $15-\mathrm{cm}$ depth. It is not clear why the presence of $\mathrm{FBC}$ in conjunction with $\mathrm{MgO}$ was so much different from $\mathrm{MgO}$ applied alone or FGD $+\mathrm{MgO}$. In the FGD + DL and DL treatments, the net total increase of exchangeable $\mathrm{Mg}$ recovered in the $0-$ to $15-\mathrm{cm}$ depth represented 12 and $17 \%$, respectively, of the amount applied (Tables 1 and 8$)$. It was much more variable for the remaining treatments $(38,21$, and $1 \%$, respectively, for the $\mathrm{MgO}, \mathrm{FGD}+\mathrm{MgO}$, and $\mathrm{FBC}+\mathrm{MgO}$ applications). 
$\mathrm{S}$ was applied only with the CCBP amendments. The results for S recovered in the CEC extract for the 1999 samples (Table 6) indicated S increasing with depth but not by very much. These data support the results noted in Table 4 for the 0 - to $15-\mathrm{cm}$ depth, indicating that $\mathrm{S}$ tended to decrease over time for the CCBP treatments. In addition, the net total increase in $\mathrm{S}$ over the 0 - to $15-\mathrm{cm}$ depth for these treatments (Table 8) indicated that less than $1 \%$ of the applied $\mathrm{S}$ remained in this depth as discussed (Ritchey, Belesky, and Harlvorson 2004). This would be expected, because soils would not retain $\mathrm{S}$ as $\mathrm{SO}_{4}^{2-}$ to any marked degree.

As discussed, the net increase of exchangeable $\mathrm{Ca}, \mathrm{Mg}$, and $\mathrm{S}$ accounted for low percentages of the amounts that were applied (Table 1). It was possible that the remainder was present as nonexchangeable species in the soil. If this were the case, it would be reasonable to expect that these species would be extracted with $0.1 \mathrm{M} \mathrm{HCl}$. From the data presented in Table 9, it was calculated that the net increases of $\mathrm{Ca}$ recovered in the $\mathrm{HCl}$ extracts for the 0 - to $2.5-\mathrm{cm}$ plus the 2.5- to $5-\mathrm{cm}$ depth intervals were $430 \%$, $330 \%$, and $270 \%$, respectively, of the net increases in exchangeable $\mathrm{Ca}$ (Table 8) for the $\mathrm{FGD}+\mathrm{DL}, \mathrm{FGD}+\mathrm{MgO}$, and $\mathrm{FBC}+\mathrm{MgO}$ applications. These amounts accounted for $45 \%, 20 \%$, and $40 \%$, respectively, of total applied $\mathrm{Ca}$ (Table 1) for these three treatments. For the $0-$ to $2.5-\mathrm{cm}$ plus the $2.5-$ to 5 -cm depth samples, the net increase of HCl-extractable Ca $\left(115.23 \mathrm{~g} \mathrm{~m}^{-2}\right)$ with the DL application was not significantly different than the applied amount of $97.7 \mathrm{~g} \mathrm{~m}^{-2}$ (Tables 1 and 9). The $95 \%$ confidence interval of net increase of $\mathrm{HCl}$-extractable $\mathrm{Ca}$ for DL treatment was $59.58 \mathrm{~g} \mathrm{~m}^{-2}, 170.88$ $\mathrm{g} \mathrm{m}^{-2}$, based on the replications. The net increases in $\mathrm{HCl}$-extractable $\mathrm{Mg}$ and $\mathrm{S}$ were also markedly greater than the corresponding net increases in exchangeable $\mathrm{Mg}$ and $\mathrm{S}$ for all treatments (Table 9). The results in Table 9 also supported the finding that much of the applied amendments remained in the upper 0 - to 5-cm depth interval of the profile.

The $\mathrm{HCl}$ extracts for the DL treatment were obtained on samples taken from 1994 through 1997 from the 0- to 15-cm depth. Values of mean soil $\mathrm{Ca}$ content in the $\mathrm{HCl}$ extract for 1994 to 1997 were 5.3, 7.3, 7.6, and

Table 9. Amount of $\mathrm{Ca}, \mathrm{Mg}$, and $\mathrm{S}\left(\mathrm{g} \mathrm{m}^{-2}\right)$ in $\mathrm{HCl}$ extracts on 0 - to 2.5-cm and 2.5- to 5-cm depth samples (1999) less the amounts present in the check plots

\begin{tabular}{lcrrrrrr}
\hline Element & $\begin{array}{c}\text { Depth } \\
(\mathrm{cm})\end{array}$ & $\mathrm{DL}$ & $\mathrm{MgO}$ & $\begin{array}{c}\text { FGD }+ \\
\mathrm{DL}\end{array}$ & $\begin{array}{c}\text { FGD } \\
\mathrm{MgO}\end{array}$ & $\begin{array}{r}\text { FBC }+ \\
\mathrm{MgO}\end{array}$ & LSD $_{0.05}$ \\
\hline $\mathrm{Ca}$ & $0-2.5$ & 103.00 & 21.21 & 204.98 & 56.23 & 211.46 & 110.07 \\
& $2.5-5$ & 12.23 & 4.66 & 17.70 & 19.07 & 41.14 & 23.47 \\
$\mathrm{Mg}$ & $0-2.5$ & 36.83 & 6.17 & 81.31 & 9.88 & 6.16 & 42.92 \\
& $2.5-5$ & 3.62 & 4.25 & 4.47 & 2.52 & 0.82 & 3.46 \\
$\mathrm{~S}$ & $0-2.5$ & 0.11 & 0.46 & 0.94 & 0.82 & 5.30 & 3.61 \\
& $2.5-5$ & -0.05 & 0.23 & 0.42 & 0.65 & 0.87 & 0.57 \\
\hline
\end{tabular}


$6.6 \mathrm{cmol}_{\mathrm{c}} \mathrm{kg}^{-1}$. Corresponding values for $\mathrm{Mg}$ were $3.9,5.5,5.5$, and $4.4 \mathrm{cmol}_{\mathrm{c}}$ $\mathrm{kg}^{-1}$, and $0.24,0.29,0.26$, and $0.27 \mathrm{cmol}_{\mathrm{c}} \mathrm{kg}^{-1}$ for $\mathrm{S}$. None of these values were significantly different between years. The $\mathrm{Ca}, \mathrm{Mg}$, and $\mathrm{S}$ contents of these extracts were compared to the values in the CEC extract on these samples given in Table 4. The $\mathrm{Ca}$ and $\mathrm{Mg}$ values were about three to four times higher than the values for the CEC extracts (data not shown). These results indicated that the ratio between these extracts remained fairly constant over time, implying that the $\mathrm{Ca}$ and $\mathrm{Mg}$ that appeared in exchangeable form must have been released from the limestone and sorbed on soil minerals early in the first year. We assume that thereafter the slowly soluble material in the applied amendments persisting in the soil continued to replenish any leaching or plant uptake losses of exchangeable $\mathrm{Ca}$ and $\mathrm{Mg}$. When the CEC-extractable $\mathrm{Ca}$ and $\mathrm{Mg}$ were subtracted from the corresponding values extracted by $\mathrm{HCl}$, the differences may be assumed to be the inactive component remaining in the soil. For some reason, these parts of the $\mathrm{Ca}$ and $\mathrm{Mg}$ sources were hard to dissolve and move. The $\mathrm{Ca} / \mathrm{Mg}$ ratios $\left(\mathrm{g} \mathrm{g}^{-1}\right)$ in the inactive form were 1.86, 1.90, 1.92, and 1.97 from 1994 through 1997. Those ratios were very close to the $\mathrm{Ca} / \mathrm{Mg}$ ratio in the applied dolomitic limestone, which was 1.91 (Table 1). This implied that such inactive component might be the original dolomitic limestone particles, probably of relatively large size.

Plant mineral concentrations and forage dry yields were determined from 1994 through 1999. The net amount of Ca and Mg taken up by plants in each year depended on the yield and plant mineral concentrations for that year. In proportion to the higher soil $\mathrm{Ca}$, a greater amount of $\mathrm{Ca}$ was taken up for the $\mathrm{FBC}+\mathrm{MgO}$ (Table 10). However, the proportion of plant uptake of $\mathrm{Ca}$ summed from 1994 through 1999 to the total applied Ca (Table 1) was low, and there were no large differences in this proportion between treatments, as illustrated by the values of $1.39 \%, 1.30 \%$, and $1.43 \%$ for FGD + DL, $\mathrm{FGD}+\mathrm{MgO}$, and $\mathrm{FBC}+\mathrm{MgO}$, respectively. The proportion of the summed plant uptake of Mg from 1994 through 1999 to total applied Mg was much higher than that of $\mathrm{Ca}$ (Tables 1 and 10). The $\mathrm{MgO}$ treatment was most effective with a percentage of $13.7 \%$.

Unpublished data (K. D. Ritchey and C. Feldhake collected on Nov. 8, 1995, and Jul. 27, 1996, from replicated soil solution ceramic lysimeters) was used to estimate the amount of annual $\mathrm{Ca}$ leaching from treatment FGD + GL. In a treatment that received only DL, the soil solution collected at the $15-\mathrm{cm}$ depth contained an average of $7 \mathrm{mg} \mathrm{kg}^{-1} \mathrm{Ca}( \pm \mathrm{SD}$ of 3.6). In a treatment that received $32,000 \mathrm{~kg} \mathrm{ha}^{-1}$ gypsum and DL, the soil solution contained an average of $317 \mathrm{mg} \mathrm{kg}^{-1}$ ( $\pm \mathrm{SD}$ of 78$) \mathrm{Ca}$. Assuming a linear relationship between soil solution $\mathrm{Ca}$ and amount of gypsum added, we estimated that the treatment FGD + DL would have $155 \mathrm{mg} \mathrm{kg}^{-1} \mathrm{Ca}$. The assumption that the relationship was linear was supported by measured values of $92 \mathrm{mg} \mathrm{kg}^{-1}$ from treatments receiving $8000 \mathrm{~kg} \mathrm{ha}^{-1}$ gypsum (but no DL), which was within $14 \mathrm{mg} \mathrm{kg}^{-1}$ of the predicted value $\left(78 \mathrm{mg} \mathrm{kg}^{-1}\right.$ ) 
Table 10. Amount of $\mathrm{Ca}$ and $\mathrm{Mg}\left(\mathrm{g} \mathrm{m}^{-2}\right)$ taken up by plants for various years from 1994 to 1999 less the amount for the check plots

\begin{tabular}{|c|c|c|c|c|c|c|c|}
\hline Element & Year & $\mathrm{DL}$ & $\mathrm{MgO}$ & $\mathrm{FGD}+\mathrm{DL}$ & $\mathrm{FGD}+\mathrm{MgO}$ & $\mathrm{FBC}+\mathrm{MgO}$ & $\mathrm{LSD}_{0.05}$ \\
\hline \multirow[t]{8}{*}{$\mathrm{Ca}$} & 1994 & 0.01 & -0.11 & 1.47 & 1.35 & 1.31 & 1.32 \\
\hline & 1995 & 0.04 & -0.06 & 0.60 & 0.57 & 0.55 & 1.02 \\
\hline & 1996 & 0.42 & -0.30 & 1.46 & 1.09 & 1.91 & 0.70 \\
\hline & 1997 & 1.29 & 0.02 & 2.10 & 1.31 & 3.48 & 1.52 \\
\hline & 1998 & 0.17 & -0.02 & 0.36 & 0.27 & 0.62 & 0.19 \\
\hline & 1999 & 0.50 & 0.05 & 0.65 & 0.37 & 1.00 & 0.11 \\
\hline & Sum & 2.42 & -0.41 & 6.64 & 4.95 & 8.87 & \\
\hline & $\%$ of applied & 2.48 & & 1.39 & 1.30 & 1.43 & \\
\hline \multirow[t]{8}{*}{$\mathrm{Mg}$} & 1994 & 0.14 & 0.22 & 0.02 & -0.04 & 0.01 & 0.16 \\
\hline & 1995 & 0.09 & 0.09 & 0.09 & 0.06 & 0.10 & 0.15 \\
\hline & 1996 & 0.79 & 1.02 & 0.51 & 0.50 & 0.52 & 0.51 \\
\hline & 1997 & 1.55 & 1.63 & 0.96 & 0.67 & 0.93 & 0.80 \\
\hline & 1998 & 0.28 & 0.37 & 0.16 & 0.14 & 0.15 & 0.11 \\
\hline & 1999 & 0.49 & 0.35 & 0.31 & 0.19 & 0.31 & 0.07 \\
\hline & Sum & 3.35 & 3.68 & 2.06 & 1.52 & 2.02 & \\
\hline & $\%$ of applied & 6.54 & 13.7 & 3.99 & 5.59 & 6.25 & \\
\hline
\end{tabular}


based on the assumed linear relationship. If the value of $155 \mathrm{mg} \mathrm{kg}^{-1}$ is representative of soil solution during the entire year and one-third of $1042 \mathrm{~mm}$ of annual precipitation leached through the profile, then the amount of $\mathrm{Ca}$ that could have leached annually from treatment FGD + DL during the early years of the experiment was estimated as $54 \mathrm{~g} \mathrm{~m}^{-2}$. This represents an annual loss of $11 \%$ of the amount that was applied to treatment FGD + DL.

In summary, the results indicated little dissolution and movement of the applied $\mathrm{Ca}$ and $\mathrm{Mg}$ except where large sulfate components were present. However, sufficient dissolution occurred to produce increases in exchangeable $\mathrm{Ca}$ and $\mathrm{Mg}$ and decreases in exchangeable $\mathrm{Al}$ that were reflected in corresponding increases in soil $\mathrm{pH}$. These beneficial effects tended to persist over time but were mostly confined to the upper $0-$ to $15-\mathrm{cm}$ depth of the profile. These effects may continue for many years (Beckie and Ukrainetz 1996). The greatest benefits appeared to be in the upper $0-$ to $5-\mathrm{cm}$ surface layer. Both $\mathrm{Ca}$ and $\mathrm{Mg}$ in calcitic dolomite tended to be immobilized in the upper 0 - to 5 -cm layer of the soil profile; the former more so than the latter.

\section{Amendment Effects on Soil Physical Properties over Small Depth Increments}

Measurements of dry bulk density $\left(\rho_{\mathrm{b}}\right.$ in $\mathrm{g} \mathrm{cm}^{-3}$ ), saturated hydraulic conductivity ( $\mathrm{K}_{\mathrm{sat}}$ in $\mathrm{cm} \mathrm{hr}^{-1}$ ), and plant-available water (PAW in $\mathrm{cm}$ water $\mathrm{cm}^{-1}$ profile) measured over small depth increments of the profile showed that significant effects, if any, of the amendments were confined to the upper 0 - to $15-\mathrm{cm}$ layer of the profile (Table 11). This was expected, because soil physical properties are to varying degrees influenced by the soil chemical properties.

The amendments had little effect on the dry bulk density, although liming materials are generally considered to enhance aggregation, thus reducing bulk density. However, silt-sized fractions dominated the uppermost layers of the profile (Table 3), and these fractions generally are less affected by the flocculating potential of divalent cations. In addition, the amount of $\mathrm{Ca}+\mathrm{Mg}$ needed to reduce bulk density may be much more than was applied to the experimental plots. The highest total $\mathrm{Ca}+\mathrm{Mg}$ addition was about $640 \mathrm{gm}^{-2}$ for the $\mathrm{FBC}+\mathrm{MgO}$ treatment (Table 1). The mass of soil in the 0- to $2.5-\mathrm{cm}$ depth per $\mathrm{m}^{2}$ would be close to $28 \mathrm{~kg}$ based on a bulk density of $1.1 \mathrm{~g} \mathrm{~cm}^{-3}$ measured for the check plots (Table 11). This translates to about $2.2 \%$ by weight of $\mathrm{Ca}+\mathrm{Mg}$, and it appears that this was not sufficient to markedly influence bulk density.

The effects of the amendments on $\mathrm{K}_{\text {sat }}$ were more pronounced (Table 11), especially in the 0 - to 5-cm depth. However, this effect did not persist with increasing depth except for the FGD $+\mathrm{MgO}$ application. The $\mathrm{K}_{\mathrm{Sat}}$ tended to fall rapidly with depth to less than $2 \mathrm{~cm} \mathrm{~h}^{-1}$, which is considered to be a moderately low to low value for agricultural soils (Barnhisel and Bertsch 1982). 
Table 11. Treatment effects on soil profile dry bulk density, saturated hydraulic conductivity, and plant-available water

\begin{tabular}{|c|c|c|c|c|c|c|c|c|}
\hline Property & Depth $(\mathrm{cm})$ & Check & DL & $\mathrm{MgO}$ & $\mathrm{FGD}+\mathrm{DL}$ & $\mathrm{FGD}+\mathrm{MgO}$ & $\mathrm{FBC}+\mathrm{MgO}$ & $\mathrm{LSD}_{0.05}$ \\
\hline \multirow[t]{6}{*}{$\rho_{\mathrm{b}}\left(\mathrm{g} \mathrm{cm}^{-3}\right)$} & $0-5$ & 1.12 & 1.09 & 1.19 & 1.10 & 1.16 & 1.20 & 0.08 \\
\hline & $5-10$ & 1.43 & 1.38 & 1.37 & 1.39 & 1.38 & 1.43 & 0.04 \\
\hline & $10-15$ & 1.54 & 1.47 & 1.49 & 1.53 & 1.45 & 1.44 & 0.06 \\
\hline & $15-20$ & 1.61 & 1.58 & 1.58 & 1.62 & 1.57 & 1.53 & 0.09 \\
\hline & $25-30$ & 1.71 & 1.65 & 1.71 & 1.70 & 1.69 & 1.64 & 0.08 \\
\hline & $30-35$ & 1.79 & 1.74 & 1.71 & 1.79 & 1.71 & 1.68 & 0.07 \\
\hline \multirow[t]{6}{*}{$\mathrm{K}_{\text {sat }}\left(\mathrm{cm} \mathrm{hr}^{-1}\right)$} & $0-5$ & 12.81 & 24.54 & 42.07 & 36.27 & 25.31 & 49.59 & 16.49 \\
\hline & $5-10$ & 6.47 & 5.82 & 9.99 & 9.89 & 6.12 & 1.49 & 6.34 \\
\hline & $10-15$ & 0.26 & 0.62 & 0.97 & 1.28 & 3.93 & 0.20 & 1.87 \\
\hline & $15-20$ & 0.06 & 0.25 & 0.29 & 1.49 & 0.44 & 0.38 & 0.96 \\
\hline & $25-30$ & 0.01 & 0.09 & 0.02 & 0.06 & 0.03 & 0.00 & 0.96 \\
\hline & $30-35$ & 0.03 & 0.20 & 0.00 & 0.20 & 0.45 & 0.22 & 0.16 \\
\hline \multirow{6}{*}{$\begin{array}{l}\text { PAW (cm } \\
\text { water per } \mathrm{cm} \\
\text { profile) }\end{array}$} & $0-2.5$ & 0.19 & 0.11 & 0.17 & 0.12 & 0.20 & 0.16 & 0.04 \\
\hline & $2.5-5$ & 0.16 & 0.12 & 0.14 & 0.18 & 0.27 & 0.14 & 0.03 \\
\hline & $7.5-10$ & 0.14 & 0.11 & 0.17 & 0.19 & 0.23 & 0.16 & 0.02 \\
\hline & $12.5-15$ & 0.09 & 0.13 & 0.16 & 0.17 & 0.16 & 0.16 & 0.02 \\
\hline & $17.5-20$ & 0.12 & 0.11 & 0.16 & 0.17 & 0.16 & 0.16 & 0.03 \\
\hline & $25-27.5$ & 0.10 & 0.10 & 0.15 & 0.12 & 0.12 & 0.15 & 0.02 \\
\hline
\end{tabular}


As was the case for bulk density, the amendments appeared to have little or no significant effect on the PAW. The PAW was defined as the difference in retention between 0.03 and $1.5 \mathrm{MPa}$ tension as measured in the pressure membrane apparatus. Increasing PAW would imply significantly increasing the microporosity. However, the texture (Table 3) of the upper layers of the soil at the experimental field was dominated by the sand- and silt-sized fractions, and the $\mathrm{Ca}$ and $\mathrm{Mg}$ either leached so rapidly that little residual was present 6 years after application or did not move to the lower and more clayey layers to produce any significant effect on the PAW.

\section{REFERENCES}

Allen, E.R. and Hossner, L.R. (1991) Factors affecting the accumulation of surfaceapplied agricultural limestone in permanent pastures. Soil Science, 151: 240-248.

Barnhisel, R. and Bertsch, P.M. (1982) Aluminum. In Methods of Soils Analysis, Part 2: Chemical and Microbiological Properties, 2nd ed., Page, A.L., Miller, R.H. and Keeney, D.R. (eds.); American Society of Agronomy: Madison, Wisconsin, 275-300.

Beckie, H.J. and Ukrainetz, H. (1996) Lime-amended acid soil has elevated pH 30 years later. Canadian Journal of Soil Science, 76: 59-61.

Belesky, D.P., Fedders, J.M., Ruckle, J.M., and Turner, K.E. (2002) Bermudagrasswhite clover-bluegrass sward production and botanical dynamics. Agronomy Journal, 94: 575-584.

Blake, G.R. (1967) Bulk density. In Methods of Soils Analysis, Part 1: Physical and Mineralogical Properties, Including Statistics of Measurement and Sampling, Black, C.A., Evans, D.D., White, J.L., Ensminger, L.E. and Clark, F.E. (eds.); ASA: Madison, Wisconsin, 374-390.

Brown, B.A., Munsell, R.I., Holt, R.F., and King, A.V. (1956) Soil reactions at various depths as influenced by time since application and amounts of limestone. Soil Science Society of America Proceedings, 20: 518-522.

Clark, R.B., Zeto, S.K., Ritchey, K.D., Wendell, R.R., and Baligar, V.C. (1995) Coal combustion by-product use on acid soil: Effects on maize growth and soil $\mathrm{pH}$ and electrical conductivity. In Agricultural Utilization of Urban and Industrial By-Products, Karlen, D.L. (ed.); ASA Spec. Publ. American Society of Agronomy, Crops Science Society of America, and Soils Science Society of America: Madison, Wisconsin; Vol. 58, 131-155.

Gee, G.W. and Bauder, J.W. (1986) Particle-size analysis. In Methods of Soils Analysis, part 1: Physical and Mineralogical Methods, 2nd ed., Klute, A. (ed.); American Society of Agronomy: Madison, Wisconsin, 383-411.

Iiyas, M., Miller, R.W., and Qureshi, R.H. (1993) Hydraulic conductivity of salinesodic soil after gypsum application and cropping. Soil Science Society of America Journal, 57: 1580-1585.

Klute, A. (1967a) Laboratory measurement of hydraulic conductivity of saturated soil. In Methods of Soils Analysis, Part 1: Physical and Mineralogical Properties, Including Statistics of Measurement and Sampling, Black, C.A., Evans, D.D., White, J.L., Ensminger, L.E. and Clark, F.E. (eds.); American Society of Agronomy: Madison, Wisconsin, 210-221. 
Klute, A. (1967b) Water capacity. In Methods of Soils Analysis, part 1: Physical and Mineralogical Properties, Including Statistics of Measurement and Sampling. Black, C.A., Evans, D.D., White, J.L., Ensminger, L.E. and Clark, F.E. (eds.); American Society of Agronomy: Madison, Wisconsin, 273-278.

Ritchey, K.D., Belesky, D.P., and Halvorson, J.J. (2004) Soil properties and clover establishment 6 years after surface application of Ca-rich by-products. Agronomy Journal, 96: 1531-1539.

Ritchey, K.D., Feldhake, C.M., Clark, R.B., and de Sousa, D.M.G. (1995) Improved water and nutrient uptake fiom subsurface layers of gypsum-amended soils. In Agricultural Utilization of Urban and Industrial By-Products, Karlen, D.L. (ed.); ASA Spec. Publ. American Society of Agronomy, Crops Science Society of America, and Soils Science Society of America: Madison, Wisconsin; Vol. 58, 157-181.

Ritchey, K.D. and Snuffer, J.D. (2002) Limestone, gypsum, and magnesium oxide influence restoration of an abandoned Appalachian pasture. Agronomy Journal, 94: 830-839.

SAS (1990). SAS/STAT User's Guide. SAS Institute: Cary, North Carolina,

Thomas, G.E. (1982) Exchangeable cations. In Methods of Soils Analysis, part 2: Chemical and Microbiological Properties; 2nd Ed.; Page, A.L., Miller, R.H. and Keeney, D.R. (eds.); American Society of Agronomy: Madison, Wisconsin, $159-165$.

Wendell, R.R. and Ritchey, K.D. (1996) High-calcium flue gas desulfurization products reduce aluminum toxicity in an Appalachian soil. Journal of Environmental Quality, 25: 1401-1410.

Wong, J.W.C. and Ho, G.E. (1991) Effects of gypsum and sewage sludge amendment on physical properties of fine bauxite refining residue. Soil Science, 152: 326-332.

Zaifnejad, M., Ritchey, K.D., Clark, R.B., Baligar, V.C., and Martens, D.C. (1996) Chemical properties of acid soil treated with coal combustion by-products and leached. Communications in Soil Science and Plant Nutrition, 27: 2783-2797. 